29. Inbar $R$, Weiss $R$, Tomljenovic L, et al Behavioral abnormalities in female mice following administration of aluminum adjuvants and the human papillomavirus (HPV) vaccine Gardasil.Immunol Res. 2017; 65(1):136-149.

30. Monsonego J. [Prevention of cervical cancer: screening, progress and perspectives]. Presse Med. 2007; 36(1 Pt 2):92-111.

31. Nacionalni vodič dobre kliničke prakse za dijagnostikovanje i lečenje raka grlića materice. Republička stručna komisija za izradu i implementaciju vodiča dobre kliničke prakse Ministarstvo zdravlja Republike Srbije. Beograd. 2012. http://www.zdravlje.gov.rs/ downloads/2012/Novembar/VodicZaDijagnostikovanjeILecenjeRakaGrlicaMaterice.pdf

32. Yanikkerem E, Piyan G, Kavlak T, Karadeniz G. Assessing the Role of Education on Turkish University Students' Knowledge about HPV and Related Diseases. Asian Pacific J Cancer Prev, 2010; 11(6):1703-1711.

33. Sandfort JR, Pleasant A. Knowledge, attitudes, and informational behaviors of college students in regard to the human papillomavirus. J Am Coll Health. 2009; 58(2):141-9.

34. Baer H, Allen S, Braun L. Knowledge of human papillomavirus infection among young adult men and women: implications for health education and research. J Community Health. 2000; 25(1):67-78.

35. Ratanasiripong NT. A review of human papillomavirus (HPV) infection and HPV vaccine-related attitudes and sexual behaviors among college-aged women in the United States. J Am Coll Health. 2012; 60(6):461-70

36. Durusoy R, Yamazhan M, Işıkgöz Taşbakan M, Ergin I, Aysin M, Pullukçu H, Yamazhan T. HPV Vaccine Awareness and Willingness of First-Year Students Entering University in Western Turkey. Asian Pacific Journal of Cancer Prevention, 2010; 11: 1-6.

37. Klug SJ, Hukelmann M, Blettner M. Knowledge about infection with human papillomavirus: a systematic review. Prev Med. 2008; 46(2):87-98.

\title{
PUŠENJE KAO FAKTOR RIZIKA ZA NASTANAK KARDIOVASKULARNIH BOLESTI KOD ZDRAVSTVENIH I PROSVETNIH RADNIKA CRNE GORE
}

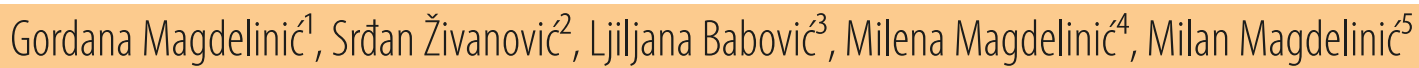 \\ ${ }^{1}$ Visoka medicinska škola Berane, ${ }^{2}$ Srednjoškolski centar Foča, ${ }^{3}$ Klinički centar Crne Gore, ${ }^{4}$ Medicinski fakultet Podgorica, \\ ${ }^{5}$ Medicinski fakultet Podgorica
}

\begin{abstract}
APSTRAKT
UVOD: Godišnje više ljudi umre od kardiovaskularnih bolesti (KVB) nego od bilo kog drugog uzroka. Faktori rizika u nastanku KVB su mnogobrojni i imaju kumulirajući efekat.Rezultati dosadašnjih studija pokazuju da pušenje cigareta ima ključnu ulogu u razvoju KVB. CILJ ISTRAŽIVANJA: Utvrditi uticaj pušenja, kod zdravstvenih i prosvjetnih radnika, na nastanak kardiovaskularnih bolesti.

Ispitanici $i$ metode istraživanja: Istrživanje je sprovedeno po tipu studije presjeka u populaciji zdravstvenih i prosvjetnih radnika opštine Berane. Uzorak je bio sastavljen od 109 zdravstvenih radnika $i 71$ prosvjetnih radnika. U istraživanju su učestvovali svi zdravstveni radnici zaposleni u Domu zdravlja „Dr Nika Labović” Beranama i svi zaposleni prosvjetni radnici zaposleni u Osnovnoj školi ,,Vuk Kardžic“ u Beranama. U istraživanju je korištena anketa, a podaci su prikupljeni prospektivno. Kao instrumenti za sprovođenje istraživanja upotrijebili su se upitnici: "Work related stress" $i$ "Cindi". Za statističku obradu podataka korišćeni su X kvadrat i ANOVA test.

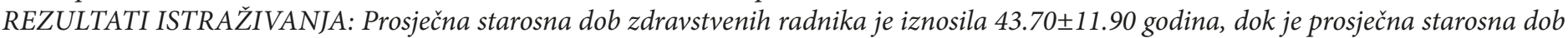
prosvjetnih radnika 42.29 10.90 godina. Više od polovine zdravstvenih i prosvjetnih radnika se izjasnilo da su pušili. Svakodnevno je pušilo $36.7 \%$ zdravstvenih radnika i 39.4\% prosvjetnih radnika. U grupi prosvjetnih radnika najveci procenat ispitanika (49.3\%) skoro nikada nije izložen duvanskom dimu na radnom mjestuU odnosu na zdravstvene radnike, prosvjetni radnici su značajno zabrinutiji zbog zdravstvenih posljedica pušenja.

ZAKLJUČAK: Kod zdravstvenih i prosvjetnih radnika opštine Berane pušenje je značajan faktor rizika za razvoj kardiovaskularnih bolesti. KLJUČNE RIJEČI: kardiovaskularne bolesti, faktori rizika, pušenje.
\end{abstract}

\footnotetext{
ABSTRACT

INTRODUCTION: Per year more people die from diabetic and vascular diseases (KVD) than from any other cause. Risk factors of the KVD are numerable and have a cumulative effect. The results of past studies shows that smoking cigarettes plays a key role in the development of KVD.

THE AIM OF THE RESEARCH: Determine to the influence of smoking in health and education workers on development of the cardiovascular diseases.

RESPONDENTS AND METHODS OF RESEARCH: Research was conducted to the type of section study in the population of health and education workers in the Berane municipality. The sample was composed of 109 health workers and 71 educational workers. In the research was participated all health workers employed in the Health Center "Dr Nika Labovic" in Berane and all educational worker employed in the Primary school „, Vuk Kardžic“ in Berane. In the research was used the questionnaire, and the data was collected prospectively. As implementing instruments for research were used questionnaires:"Work related stress" and "Cindy". $\chi$ square and ANOVA test were used for statistical data processing.
}

RESEARCH RESULTS: The average age of health workers was $43.70 \pm 11.90$ years, while the average age of educational workers was 42.29 
\pm 10.90 years. More than half of health and education workers said that smoking. $36.7 \%$ of health workers and $39.4 \%$ of educational workers smoked daily. In the group of educational workers, the highest percentage of respondents (49.3\%) are almost never exposed to tobacco smoke at work. In relation to health workers, educational workers are significantly worried about health effects of smoking.

CONCLUSION: In the health and education workers of Berane municipality, smoking is a significant risk factor for the development of cardiovascular diseases.

KEY WORDS: cardiovascular disease, risk factors, smoking.

\section{UVOD}

$\mathrm{K}$ ardiovaskularne bolesti (KVB) predstavljaju značajan, kako zdravstveni, tako i socijalno- ekonomski problem savremenog društva. Vodeći su uzrok smrti sa preko $50 \%$ učešća, najviše pogoršavaju kvalitet života, uzrokuju invalidnost, ekonomski slabe naciju i skraćuju očekivanu dužinu života. Svaki četvrti stanovnik u razvijenim zemljama boluje od ishemijske bolesti srca i životni vijek mu je skraćen za u prosjeku sedam godina (1).

Na većinu najznačajnijih faktora rizika koji doprinose nastanku bolesti srca i krvnih sudova svaka osoba može uticati, smanjujući ih, isključujući ih iz svog života. To su promjenljivi faktori rizika. Postoje faktori rizika na koje nije moguće uticati, oni su nepromjenljivi faktori. Neminovno starenje označava prisustvo različitih uticaja, faktora rizika i njihovo nagomilavanje sa godinama života, zbog čega su starije osobe pod većim rizikom. Rizik se udvostručava na svakih 10 godina poslije 55. godina života (2).

Godine 1964. objavljen je izvještaj američke zdravstvene službe (Surgeon Generals Report on Smoking and Health) u kojem je pušenje definitivno proglašeno rizičnim faktorom i uzrokom niza bolesti koje znatno smanjuju kvalitet života i dovode do prerane smrti. Od tada su brojne kliničke, laboratorijske i epidemiološke studije u svijetu ispitivale učinke pušenja na zdravlje i potvrdile da konzumiranje duvana i duvanskih proizvoda i to posebno pušenje cigareta, ali i izloženost duvanskom dimu, odnosno tzv. pasivno pušenje, znatno doprinose obolijevanju i prijevremenom umiranju od niza bolesti (3-5).

Duvanski dim sadrži preko 4.000 različitih hemijskih sastojaka. Najpoznatija od njih je nikotin - koji stvara zavisnost. Organizam se postepeno privikava na nikotin (6). Djelovanjem nikotina na nadbubrežnu žljezdu oslobađa se adrenalin i noradrenalin, što dovodi do povećanja frekvencije srca, stiskanje malih krvnih sudova i povećanje krvnog pritiska. Uz navedene promjene sastojci duvanskog dima inhalirani u pluća prelaze u krvotok i uzrokuju oštećenja na endotelnim zidovima krvnih žila. Smatraju se aktivatorima pucanja ateroma i učesnicima u trombogenezi. Kod dugogodišnjih pušača, pušenje je odgovorno za 50\% svih smrtnih ishoda koji su se mogli izbjeći, a pola od njih je od kardiovaskularnih bolesti (KVB). Ovaj nepovoljan uticaj pušenja je povezan sa količinom duvana koji se dnevno puši i sa dužinom trajanja pušenja. Taj uticaj je prisutan i kod muškaraca i kod žena, a može da bude i veći kod žena, što ukida relativnu zaštitu žena od aterosklerotičnih oboljenja (7).

Prestanak pušenja značajno smanjuje rizik od smrti bilo kojeg uzroka u bolesnika s KVB i može se mjeriti s drugim sekundarnim preventivnim postupcima. Prestankom pušenja u bolesnika s KVB rizik tokom iduće 2-3 godine padne na nivo nepušača koji imaju $\mathrm{KVB}$, a kod asimptomatskih bolesnika potrebno je 8 do 10 godina da se dosegne nivo rizika nepušača (8).

Cilj ovog istraživanja je bio utvrditi zastupljenost pušača kod zdravstvenih i prosvjetnih radnika.

\section{ISPITANICI I METODE ISTRAŽIVANJA}

$\mathrm{U}$ istraživanju su učestvovali svi zdravstveni radnici zaposleni u Domu zdravlja „Dr Nika Labović”u Beranama (ukupno 109 zdravstvenih radnika) i svi zaposleni prosvjetni radnici u Osnovnoj školi „Vuk Kardžić“ u Beranama (ukupno 71 prosvjetni radnik).

U istraživanju je korištena specijalno dizajnirana anketa. Podaci su prikupljeni prospektivno. Kao instrumenti za sprovođenje istraživanja upotrijebili su se upitnici: Work related stress i Cindi. Nakon provjere integriteta podataka obavljena je statistička analiza u programu IBM SPSS Statistics v. 20.0 for Windows. Korišten je hi-kvadrat i ANOVA test.

Kriterijumi za uključivanje u istraživanje:

- da osobe nisu mlađe od 18 i ne starije od 65 godina;

- da je svaki ispitanik stanovnik opštine Berane;

- da je ispitanik zdravstveni radnik Doma zdravlja „Dr. Nika Labović” ili prosvjetni radnik Osnovne škole „Vuk Karadžić”u Beranama;

- da svaki ispitanik dobrovoljno učestvuje u istraživanju.

Kriterijumi za isključivanje iz istraživanja:

- da su osobe mlađe od 18 i starije od 65 godina;

- da ispitanici nisu stanovnici opštine Berane;

- da ispitanik nije zdravstveni radnik Doma zdravlja „Dr. Nika Labović“i nije prosvjetni radnik Osnovne škole „Vuk Karadžić“ u Beranama;

- da ispitanik nije dobrovoljni učesnik istraživanja.

\section{REZULTATI ISTRAŽIVANJA}

Istraživanjem je obuhvaćeno 180 ispitanika, koji su prema kriterijima za uključivanje u istraživanju, podjeljeni u dvije grupe. Prvoj grupi pripadalo je 109 (60.6\%) zdravstvenih radnika, dok drugoj grupi 71 (39.4\%) prosvjetni radnik u opštini Berane. Primjenom hi kvadrat testa nije ustanovljena statistički značajna razlika u polnoj strukturi ispitanika ispitivanih grupa, tako da su u obje ispitivane grupe dominirale žene, $\chi 2=0.024 ; \mathrm{p}=0.507$. $\mathrm{U}$ grupi zdravstvenih radnika bilo je ukupno $22.9 \%$ ispitanika muškog i $77.1 \%$ ispitanika ženskog pola. U grupi prosvjetnih radnika bilo je ukupno $23.9 \%$ ispitanika muškog i $76.1 \%$ ženskog pola. Prosječna starosna dob zdravstvenih radnika je iznosila $43.70 \pm 11.90$ godina, dok je prosječna starosna dob prosvjetnih radnika 42.29 10.90 godina. Primjenom Anova testa nije ustanovljena statistički značajna razlika u prosječnoj starosnoj dobi ispitanika ispitivanih grupa, $\mathrm{F}=0.644 ; \mathrm{p}=0.423$.

Tabela 1. prikazuje učestalost pušenja među članovima porodice. Kod 56\% zdravstvenih radnika neko u porodici puši, dok kod $56.3 \%$ prosvjetnih radnika takođe neko u porodici puši. Primjenom hi kvadrat testa nije ustanovljena statistički značajna

\section{Korespondent:}


razlika u učestalosti pušenja među članovima porodice, $\chi 2=0.002$; $\mathrm{p}=0.542$.

\section{Tabela 1. Učestalost pušenja među članovima porodice}

\begin{tabular}{|l|l|c|c|c|}
\hline & & \multicolumn{2}{|c|}{ Grupe } & \multirow{2}{*}{ Ukupno } \\
\cline { 2 - 5 } & & Zdravstveni radnici & Prosvjetni radnici & \\
\hline \multirow{2}{*}{ ne, niko ne puši } & Broj & 48 & 31 & 79 \\
\hline \multirow{2}{*}{ da, neko je pušač } & $\%$ & $44,0 \%$ & $43,7 \%$ & $43,9 \%$ \\
\hline \multirow{2}{*}{ Ukupno } & Broj & 61 & 40 & 101 \\
\hline & $\%$ & $56,0 \%$ & $56,3 \%$ & $56,1 \%$ \\
\hline & Broj & 109 & 71 & 180 \\
\hline & $\%$ & $100,0 \%$ & $100,0 \%$ & $100,0 \%$ \\
\hline & & & $x 2=0.002 ; p=0.542$ \\
\hline
\end{tabular}

Najveći procenat zdravstvenih radnika duvanskom dimu na radnom mjestu je izloženo između 1-5 sati (35.2\%), dok je $23.1 \%$ zdravstvenih radnika odgovorilo da skoro nikada nisu izloženi duvanskom dimu. U grupi prosvjetnih radnika najveci procenat ispitanika (49.3\%) skoro nikada nije izložen duvanskom dimu na radnom mjestu, te je primjenom hi kvadra testa ustanovljena statistički značajna razlika u dužini izlaganja duvanskom dimu na radnom mjestu $u$ odnosu na ispitivane grupe, $\chi 2=11.335 ; \mathrm{p}=0.001$ (Grafikon 1.)

\section{Grafikon 1. Dužina izlaganja duvanskom dimu na radnom mjestu}

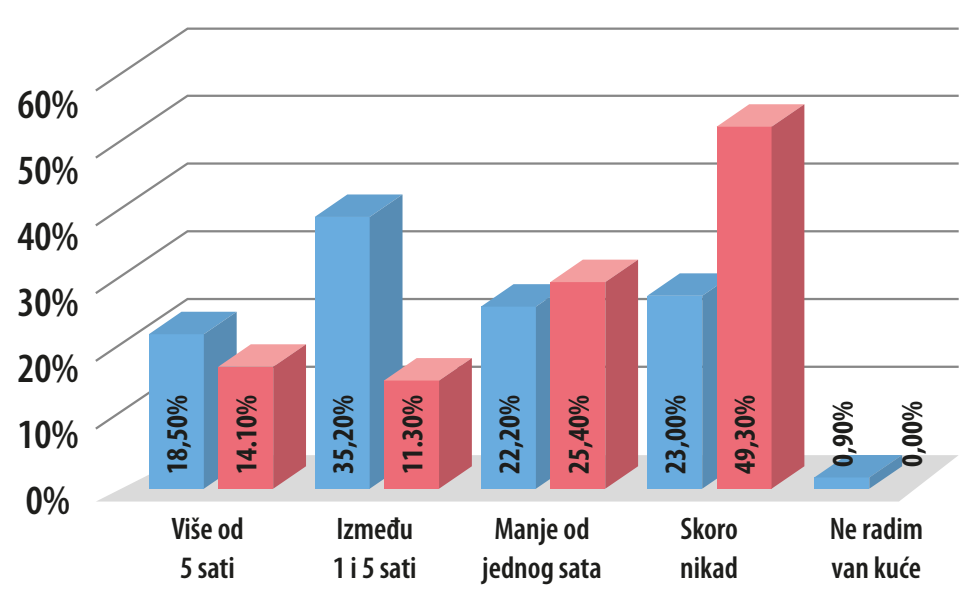

Zdravstveni radnici $\square$ Prosvjetni radnici

\section{Grafikon 2. Učestalost pušenja među ispitivanim grupama}

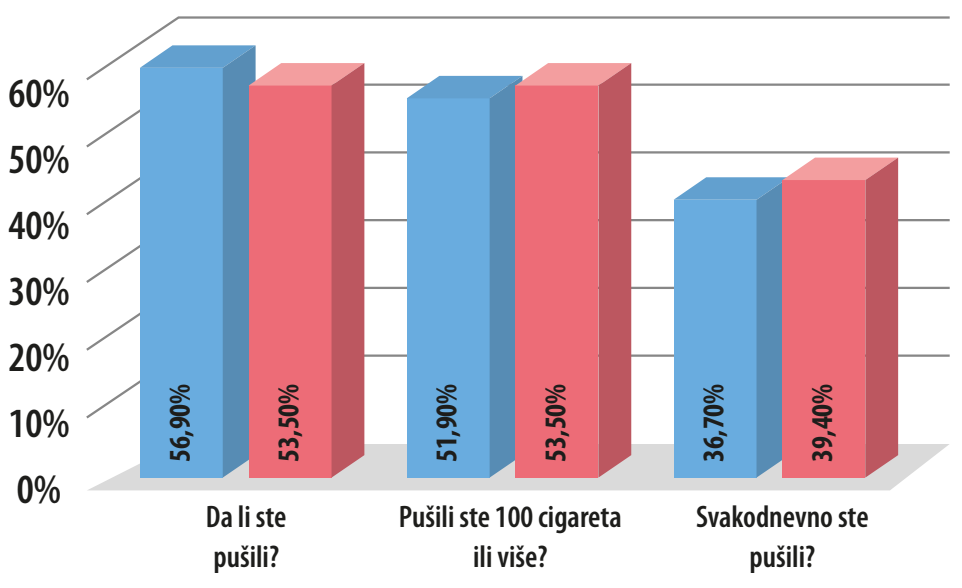

Zdravstveni radnici $\square$ Prtosvjetni radnici
Od ukupnog broja zdravstvenih radnika $56.9 \%$ je dalo pozitivan odgovor da su pušili, dok je taj procenat u grupi prosvjetnih ranika 53.5\%, te primjenom hi kvadrat testa nije ustanovljena statistički značajna razlika, $\chi 2=0.195 ; \mathrm{p}=0.386$. U grupi zdravstvenih radnika 51.9\% ispitanika je ispušilo 100 cigareta i više u životu, dok je u grupi prosvjetnih ranika taj procenat $53.5 \%$ i nije ustanovljena statistički značajna razlika, $\chi 2=0.048 ; \mathrm{p}=0.474$. Svakodnevno je pušilo $36.7 \%$ zdravstvenih radnika i $39.4 \%$ prosvjetnih radnika. Primjenom hi kvadrat testa nije ustanovljena statistički značajna razlika u učestalosti svakodnevnog konzumiranja cigareta u odnosu na ispitivane grupe, $\chi 2=0.136 ; \mathrm{p}=0.415$ (Grafikon 2.).

Najveći procenat ispitanika obje ispitivane grupe izjasnio se da trenutno ne konzumira cigarete i to $65.1 \%$ zdravstvenih i $70.4 \%$ prosvjetnih radnika. Cigarete svakodnevno konzumira $25.7 \%$ zdravstvenih i $22.5 \%$ prosvjetnih radnika. Povremeno konzumira cigarete $9.2 \%$ zdravstvenih i $7 \%$ prosvjetnih radnika. Primjenom hi kvadrat testa nije ustanovljena statistički značajna razlika u trenutnom statusu pušenja između zdravstvenih i prosvjetnih radnika, $\chi 2=0.415 ; \mathrm{p}=0.519$ (Tabela 2).

Tabela 2. Trenutni status pušenja

\begin{tabular}{|c|c|c|c|c|}
\hline & & \multicolumn{2}{|c|}{ Grupe } & \multirow[t]{2}{*}{ Ukupno } \\
\hline & & Zdravstveni radnici & Prosvjetni radnici & \\
\hline \multirow[t]{2}{*}{ Da, svakodnevno } & Broj & 28 & 16 & 44 \\
\hline & $\%$ & $25,7 \%$ & $22,5 \%$ & $24,4 \%$ \\
\hline \multirow[t]{2}{*}{ Povremeno } & Broj & 10 & 5 & 15 \\
\hline & $\%$ & $9,2 \%$ & $7,0 \%$ & $8,3 \%$ \\
\hline \multirow[t]{2}{*}{ Ne, nikako } & Broj & 71 & 50 & 121 \\
\hline & $\%$ & $65,1 \%$ & $70,4 \%$ & $67,2 \%$ \\
\hline \multirow[t]{2}{*}{ Ukupno } & Broj & 109 & 71 & 180 \\
\hline & $\%$ & $100,0 \%$ & $100,0 \%$ & $100,0 \%$ \\
\hline \multicolumn{5}{|c|}{$X 2=0.415 ; p=0.519$} \\
\hline
\end{tabular}

Analizom prosječnog broja cigareta koje ispitanici ispitivanih grupa ispuše na dnevnom nivou, nije ustanovljena statistički značajna razlika između zdravstvenih $(17.9 \pm 12.37)$ i prosvjetnih radnika (15 \pm 9.11$), \mathrm{F}=0.644 ; \mathrm{p}=0.423$ (Tabela3 )

Tabela 3. Prosječan broj cigareta na dnevnom nivou

\begin{tabular}{|l|c|c|c|c|c|c|}
\hline & $\mathrm{N}$ & $\mathrm{X}$ & $\mathrm{SD}$ & $\mathrm{SEM}$ & Minimum & Maximum \\
\hline Zdravstveni radnici & 52 & 17,90 & 12,37 & 1,71 & 1,00 & 60,00 \\
\hline Prosvjetni radnici & 36 & 15,00 & 9,11 & 1,51 & 1,00 & 40,00 \\
\hline & & & & & $\mathrm{F}=0.644 ; \mathrm{p}=0.423$ \\
\hline
\end{tabular}

Od ukupnog broja ispitanika obje ispitivane grupe koji su odgovorili na pitanje o želji za prestankom konzumiranja cigareta, 19 (30.6\%) zdravstvenih i 11 (28.9\%) prosvjetnih radnika je odgovorilo pozitivno tj. da bi voljeli da prestanu da puše. Primjenom hi kvadrat testa nije ustanovljena statistički značajna razlika u želji za prestanak konzumiranja cigareta u odnosu na ispitivane grupe, $\chi^{2}=1.120 ; p=0.290$. (Tabela 4 ).

Primjenom hi kvadrat testa nije ustanovljena statistički značajna razlika u pokušaju apstinencije od duvana u odnosu na ispitivane grupe, $\chi 2=1.082 ; p=0.298$. Najveći procenat ispitanika je pokušao da prestane da puši prije više od godinu dana i to $43.6 \%$ zdravstvenih i $58.6 \%$ prosvjetnih radnika. Nikada nije prestalo da puši $27.3 \%$ zdravstvenih i $27.6 \%$ prosvjetnih radnika (Grafikon 3). 


\section{Tabela 4. Želja za prestanak konzumiranja cigareta}

\begin{tabular}{|c|c|c|c|c|}
\hline & & \multicolumn{2}{|c|}{ Grupe } & \multirow[t]{2}{*}{ Ukupno } \\
\hline & & Zdravstveni radnici & Prosvjetni radnici & \\
\hline \multirow[t]{2}{*}{$\mathrm{Ne}$} & Broj & 8 & 2 & 10 \\
\hline & $\%$ & $12,9 \%$ & $5,3 \%$ & $10,0 \%$ \\
\hline \multirow[t]{2}{*}{$\mathrm{Da}$} & Broj & 19 & 11 & 30 \\
\hline & $\%$ & $30,6 \%$ & $28,9 \%$ & $30,0 \%$ \\
\hline \multirow[t]{2}{*}{ Nisam siguran/na } & Broj & 11 & 8 & 19 \\
\hline & $\%$ & $17,7 \%$ & $21,1 \%$ & $19,0 \%$ \\
\hline \multirow[t]{2}{*}{ Ne pušim više } & Broj & 24 & 17 & 41 \\
\hline & $\%$ & $38,7 \%$ & $44,7 \%$ & $41,0 \%$ \\
\hline \multirow[t]{2}{*}{ Ukupno } & Broj & 62 & 38 & 100 \\
\hline & $\%$ & $100,0 \%$ & $100,0 \%$ & $100,0 \%$ \\
\hline
\end{tabular}

\section{Grafikon 3. Pokušaj apstinencije od duvana u trajanju od najmanje 24h}

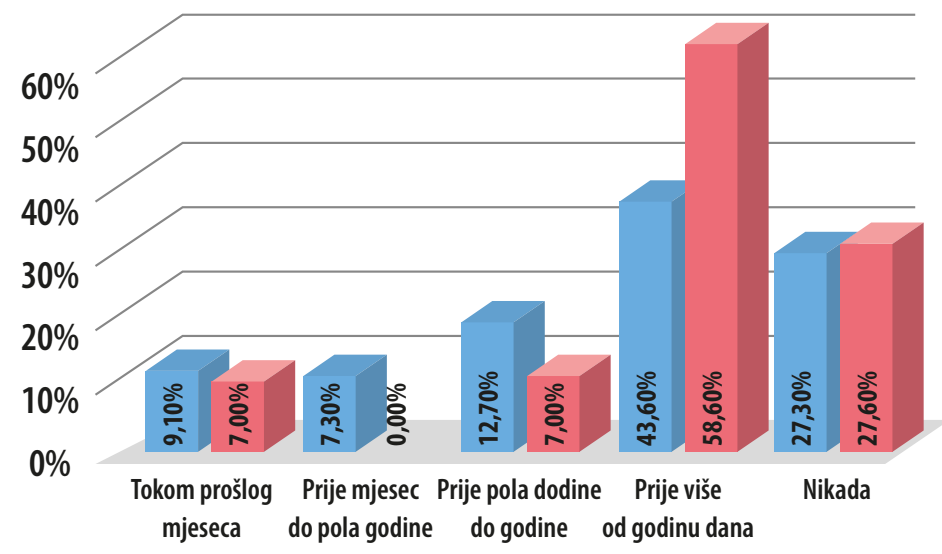

Zdravstveni radnici $\square$ Prosvjetni radnici

Prosvjetni radnici su bili statistički značajno više zabrinuti zbog štetnih zdravstvenih posljedica pušenja u odnosu na zdravstvene radnike, $\chi 2=9.018 ; \mathrm{p}=0.003$ (Tabela 5.).

\section{Tabela 5. Zabrinutost zbog štetnih zdravstvenih posljedica pušenja}

\begin{tabular}{|c|c|c|c|c|}
\hline & & \multicolumn{2}{|c|}{ Grupe } & \multirow[t]{2}{*}{ Ukupno } \\
\hline & & Zdravstveni radnici & Prosvjetni radnici & \\
\hline \multirow[t]{2}{*}{ Veoma zabrinut/a } & Broj & 16 & 17 & 33 \\
\hline & $\%$ & $26,2 \%$ & $45,9 \%$ & $33,7 \%$ \\
\hline \multirow[t]{2}{*}{ Donekle zabrinut/a } & Broj & 16 & 13 & 29 \\
\hline & $\%$ & $26,2 \%$ & $35,1 \%$ & $29,6 \%$ \\
\hline \multirow{2}{*}{$\begin{array}{l}\text { Ne previše } \\
\text { zabrinut/a }\end{array}$} & Broj & 13 & 5 & 18 \\
\hline & $\%$ & $21,3 \%$ & $13,5 \%$ & $18,4 \%$ \\
\hline \multirow{2}{*}{$\begin{array}{r}\text { Nisam uopšte } \\
\text { zabrinut/a }\end{array}$} & Broj & 16 & 2 & 18 \\
\hline & $\%$ & $26,2 \%$ & $5,4 \%$ & $18,4 \%$ \\
\hline \multirow[t]{2}{*}{ Ukupno } & Broj & 61 & 37 & 98 \\
\hline & $\%$ & $100,0 \%$ & $100,0 \%$ & $100,0 \%$ \\
\hline \multicolumn{5}{|c|}{$X 2=9.018 ; p=0.003$} \\
\hline
\end{tabular}

Primjenom hi kvadrat testa nije ustanovljena statistički značajna razlika u dobivanju savjeta za prestanak pušenje od određenih osoba u odnosu na ispitivanu grupu. Najveći procenat ispitanika je savjete o prestanku pušenja dobijao od članova porodice $(\mathrm{p}=0.327)$ i to $40.3 \%$ zdravstvenih i $51.7 \%$ prosvjetnih radnika (Grafikon 4.).

\section{Grafikon 4. Savjet o prestanku pušenja}

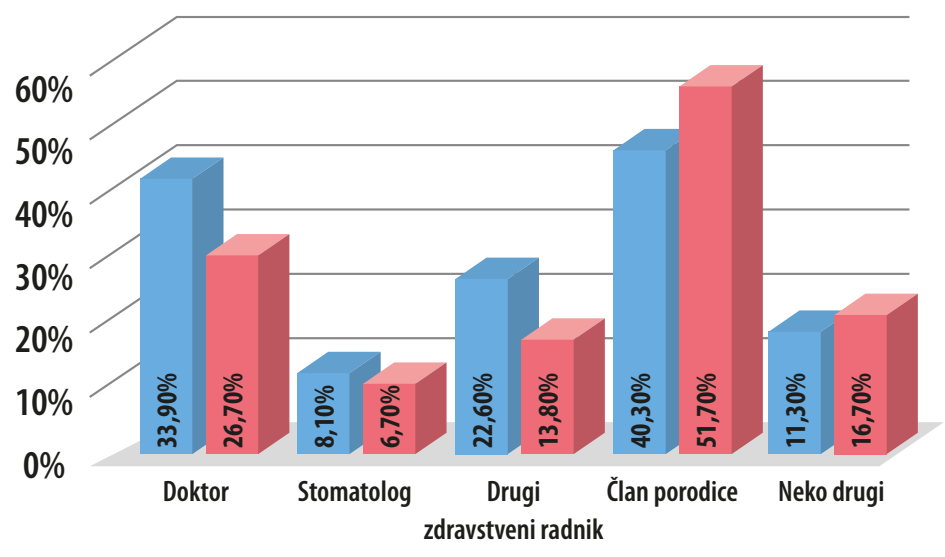

Zdravstveni radnici $\square$ Prosvjetni radnici

\section{DISKUSIJA}

Analizom navike pušenja u ovom istraživanju došli smo do sljedećih podataka. Kod više od polovine ispitanika i jedne i druge grupe neko u porodici puši, tako da nije ustanovljena statistički značajna razlika u učestalosti pušenja među članovima porodice. Najveći broj zdravstvenih radnika na radnom mjestu je izložen duvanskom dimu u prosjeku od 1-5 sati, a samo njih $20 \%$ se izjasnilo da nikada nisu izloženi duvanskom dimu, dok u grupi prosvjetnih radnika najveći broj njih nikada nije izložen duvanskom dimu na radnom mjestu, tako da je uočena statistički značajna razlika između ove dvije grupe ispitanika.

Više od polovine zdravstvenih i prosvjetnih radnika se izjasnilo da su pušili. Više od polovine ispitanika se izjasnilo da je ispušilo više od 100 cigareta u životu. Svakodnevno je pušilo $36.7 \%$ zdravstvenih radnika i $39.4 \%$ prosvjetnih radnika. Svakodnevno puši $25.7 \%$ zdravstvenih radnika i $22.5 \%$ prosvjetnih radnika. Najveći procenat ispitanika obje ispitivane grupe izjasnio se da trenutno ne konzumira cigarete. Povremeno konzumira cigarete 9.2\% zdravstvenih i 7\% prosvjetnih radnika. Ustanovili smo da ne postoji statistički značajna razlika u prosječnom broju cigareta koje se dnevno popuše.

$\mathrm{Na}$ osnovu podataka istraživanja o zdravstvenom stanju stanovništva Crne Gore iz 2000. godine procjenjeno je da u populaciji odraslog stanovništva (lica iznad 20 godina starosti), prevalencija svakodnevnih pušača iznosila $37,4 \%$ (28,5\% u populaciji žena i $47,7 \%$ u populaciji muškaraca), uz još $6,1 \%$ povremenih pušača, što je ukupno iznosilo $43,5 \%$. Studija zdravstvenog stanja populacije Crne Gore iz 2008. ukazuje da je došlo do značajnog smanjenja prevalencije konzumiranja duvana među stanovništvom Crne Gore i da ona trenutno iznosi 32,7\% (26,4\% svakodnevnih pušača i $6,3 \%$ povremenih pušača). Među ženama puši njih $29 \%$ (26\% svakodnevno i $6 \%$ povremeno) a među muškarcima njih $36,7 \%$ (30\% svakodnevno i 6,7\% povremeno). Procjene Instituta za javno zdravlje Crne Gore iz Podgorice su da godišnje u Crnoj Gori od posljedica pušenja duvana umire oko 800-1000 osoba (9).

U Srbiji je u 2013. godini 34,7\% stanovnika pušilo (svakodnevno ili povremeno), što ne predstavlja značajnu promjenu u odnosu na učestalost pušenja u 2006. godini (33\%). Pušenje je i dalje ostala zastupljenija navika kod muškaraca (37,9\%), nego kod žena (31,6\%). U godini koja je predhodila istraživanju svaki treći pušač (33\%) je pokušao da ostavi pušenje, dok je svaki drugi (58\%) bio zabrinut za sopstveno zdravlje zbog posledica izloženosti du- 
vanskom dimu (10). Statistički značaju razliku u pokušaju apstinencije između naše dvije ispitivane grupe nismo uočili, jer više od polovine prosvjetnih radnika i nešto manje od polovine zdravstvenih radnika su pokušali da prestanu da puše prije godinu dana. U odnosu na zdravstvene radnike, prosvjetni radnici su značajno zabrinutiji zbog zdravstvenih posljedica pušenja.

Prema rezultatima istraživanja provedenog 2015. godine, $\mathrm{Hr}-$ vatskog zavoda za javno zdravstvo o upotrebi duhana u odrasloj

\section{ZAKLJUČAK}

Poznavanje povezanosti bioloških i psihosocijalnih faktora i koronarne bolesti ukazuje na neophodnost planiranja novih preventivnih mjera, koje ne treba usmjeriti samo ka usvajanju zdravog stila života (promjene navika u ishrani, prestanak pušenja, povećanje fizičke aktivnosti, kontrola tjelesne mase), već i ka modifikaciji emocionalnog reagovanja i ponašanja prema promjenama u porodici, na poslu i u socijalnom okruženju individue (12).

Kod zdravstvenih i prosvjetnih radnika opštine Berane pušenje je značajan faktor rizika za razvoj kardiovaskularnih bolesti, što navodi na potrebu mjera prevencije i promocije zdravih stilova života.

U ovom radu utvrdili smo značajne nepravilnosti zdravst- populaciji u Hrvatskoj, puši 31,1\% stanovništva (27,5\% svakodnevno, a 3,6\% povremeno) (11), što je veći procenat nego u populaciji Crne Gore i opštine Berane.

Kao što vidimo u navedenim rezultatima, postotak zdravstvenih i prosvjetnih radnika koji konzumiraju cigarete je veoma visok, kao i postotak pušača opšte populacije Crne Gore (32,7\%) i Hrvatske (31,1\%), dok Republika Srbija 2013. godine bilježi 34,7\% pušača, što je takođe zabrinjavajući podatak.

venog ponašanja kod obje ispitivane grupe, $u$ vidu konzumiranja cigareta, izloženosti duvanskom dimu, želji za prestankom pušenja i sl. Razlike među grupama nisu bile statistički značajne, sem u većoj izloženosti duvanskom dimu zdravstvenih radnika u odnosu na prosvjetne kao i u većoj zabrinutosti prosvjetnih radnika zbog štetnih zdravstvenih posljedica pušenja. Profesija zdravstvenih i prosvjetnih radnika je zdravstveno-edukativnog karaktera i veoma odgovorna (obavezujuća prema korisnicima usluga). S toga, značaj ovog istraživanja je u cilju boljeg i kvalitetnijeg zdravstvenog ponašanja čiji bi konačni uspjeh bio zdravo stanovništvo.

\section{LITERATURA}

1. Prevencija kardiovaskularnih bolesti. Nacionalni vodič za lekare u primarnoj zdravstvenoj zaštiti. Beograd, Novembar 2005.

2. Berenson GS, Srinivasan SR, Wattigney WA, Harsha DW. Obesity and cardiovascular risk in children Ann NY Acad Sci. 1993;699:93-103.

3. Anderson HC, Mc Gregor DH, Tanimura A. Mechanisms of Calcification in Atherosclerosis in "Pathobiology of the Human Atherosclerotic Plaque”, ed Glagov S., Newman W.P., Schaffer S.A., N.Z. Springer. 1990: 32-38.

4. Rosengen A, Tibblin G, Wilhelmsen L. Self-perceived phychological stress and incidence of coronary artery disease in middle-aged men. Am J Cardiol 1991, 68:1171-5.

5. Henry C McGill, Jr, C Alex McMahan, Edward E Herderick, Gray T Malcom, Richard E Tracy, Jack P. Strong and the Pathobiological Determinants of Atherosclerosis in Youth (PDAY) Research Group. Origin of atherosclerosis in childhood and adolescence. American Journal of Clinical Nutrition, Vol. 72, No. 5, 1307S-1315s, November 2000.Presented at the symposium Fat Intake During Childhood, held in Houston, June 8-9, 1998.

6. Shankar RR, Eckert GJ, Saha C, Tu W, Pratt JH.The Change in Blood Pressure during Pubertal Growth. J Clin Endocrinol Metab. 2005;90(1):163-7.

7. Stamler R, Stamler J, Riedlinger W.F et al. Weight and blood pressure. Findings in hypertension screenings of 1 million Ameri-cans. J Am Med Assoc 1978, 240: 1607-1611.

8. Critchley JA, Capewell S. Mortality risk reduction associated with smoking cessation in patients with coronary heart disease: a systematic review. JAMA. 2003;290:86-97.

9. Kavarić N. Gojaznost kao faktor rizika nastanka kardiovaskularnih poremećaja u dece školskog uzrasta. Doktorska disertacija. 2013. Podgorica

10. Institut za javno zdravlje Srbije „dr Milan Jovanović Batut“. Zdravstveno statistički godišnjak Republike Srbije 2015. Beograd, 2016.

11. Dečković V, Ivičević Uhernik A, Mihel S. Istraživanje o upotrebi duhana u odrasloj populaciji Republike Hrvatske. Hrvatski zavod za javno zdravstvo. 2015: 4-24.

12. Brigitta Maćešić, Branka Špehar. Prevencija kardiovaskularnih bolesti u primarnoj zdravstvenoj zaštiti. SG/NJ 2014;19:30-41. 